\title{
Response of tap- and creeping-rooted alfalfas to defoliation patterns
}

\author{
ABDALLA O. GDARA, RICHARD H. HART, AND JOHN G. DEAN
}

\section{Abstract}

Under grazing, creeping-rooted alfalfa (Medicago sativa L.) cultivars have been reported to be more productive and have higher survival than tap-rooted cultivars. To determine if differences in persistence could be related to response to defoliation patterns, we clipped 3 tap- and 3 creeping-rooted alfalfa cultivars. Different fractions of the total number of stems were clipped to different stubble heights every 21 days. Both tap- and creepingrooted cultivars responded similarly to defoliation. Maximum forage production was obtained when one-third of the stems on a plant were cut back to $5 \mathrm{~cm}$ above the ground at each harvest. The lowest forage production was obtained when all stems on a plant were cut back to $5 \mathrm{~cm}$. The most lenient defoliation (one-third of the height of one-third of the stems removed at each harvest) maximized total herbage production (forage plus stubble) but only $32 \%$ of the herbage was harvested as forage, leaving $68 \%$ as unharvested stubble. Severe defoliation every 21 days decreased the concentration of total nonstructural carbohydrate in the roots and reduced total root biomass. Thirteen alfalfa cultivars responded similarly to grazing when seeded in dense stands. The greater persistence of creeping-rooted alfalfa cultivars under grazing does not appear to be a result of greater intrinsic productivity or more rapid recovery from defoliation. The lateral spread of individual creeping-rooted plants in open stands may increase the probability that some stems will escape defoliation at each grazing; these stems then contribute to rapid recovery from grazing and to plant survival.

Key Words: Medicago sativa L., grazing, clipping, root reserves, survival, forage production

Alfalfa (Medicago sativa L.) has been grazed for many years in different areas of the world with varying degrees of success. However, stand deterioration is common when alfalfa is grazed. Alfalfa cultivars differ in type of root or crown, stem number, stem height, extent of axillary branching, and site and activity of regrowth; all these characteristics may influence their response to grazing.

Newly developed cultivars of rhizomatous or creeping-rooted alfalfas have been reported to survive longer and produce more forage under grazing than tap-rooted alfalfas (Clark 1960, Kilcher and Heinrichs 1966, Ashford and Heinrichs 1967, Daday 1968. Rumbaugh and Pedersen 1979, Counce et al. 1984, Heinrichs and Bolton 1985, Berdahl et al. 1989, Smith et al. 1989). In contrast, Leach (1969) reported that creeping-rooted alfalfa cultivars had no advantage in either production or survival when grazed in Australia. He also pointed out that the effect of grazing on alfalfa depended on the time, intensity, and frequency of defoliation.

Our objectives were to evaluate the forage production of creeping-rooted and tap-rooted alfalfas under lenient to severe clipping, and to relate the survival of cultivars under actual grazing to their responses to grazing simulated by clipping.

Authors are former research assistant, Range Science Dept., Colorado State University, Fort Collins 80523; and range scientist and agronomist (deceased), USDA, Agricultural Research Service, High Plains Grasslands Research Station, Cheyenne, Wyo. 82009. Gdara's current address is 18565 A East Colima Road, Rowland Heights, Calif. 91748 .

Manuscript accepted 21 April 1990
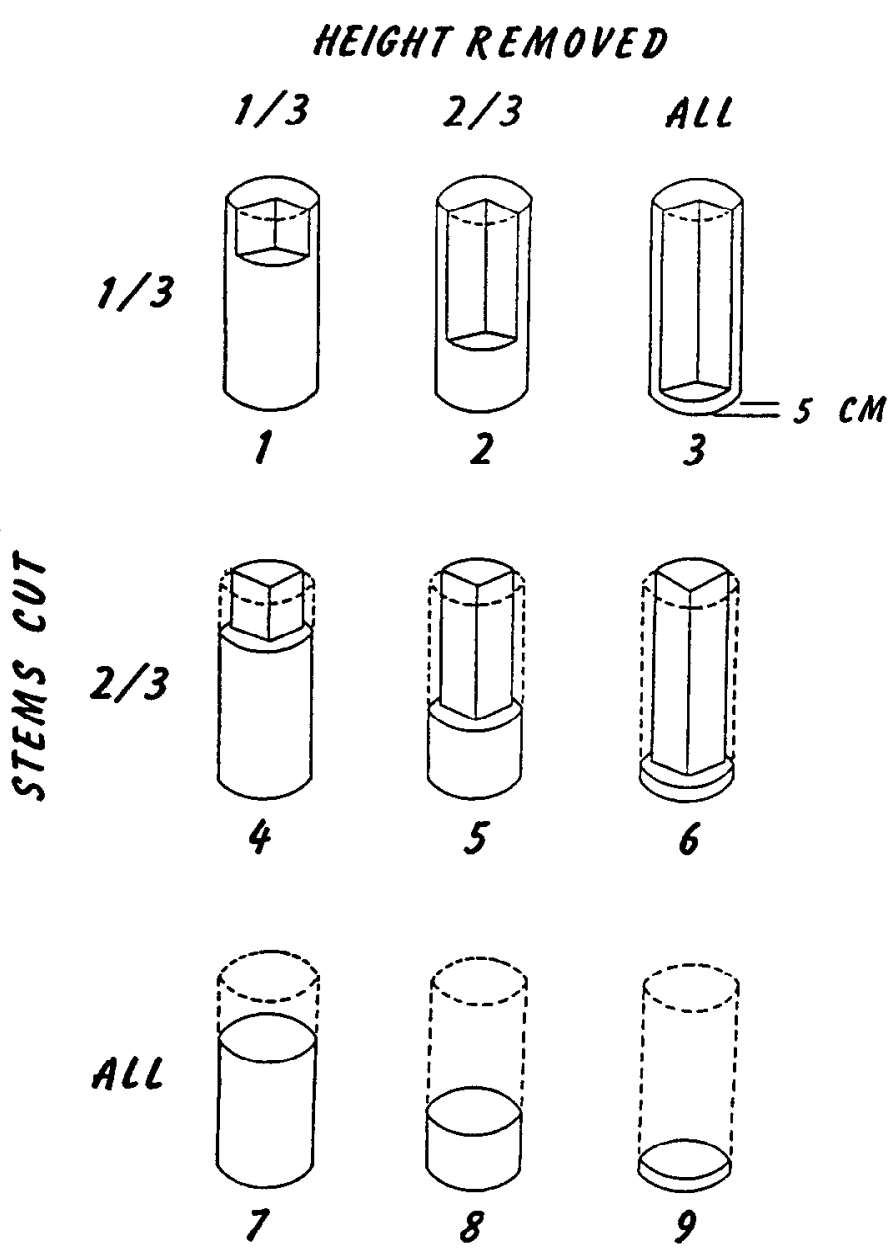

Fig. 1. Clipping treatments; dotted lines indicate portions removed.

\section{Materials and Methods}

Two studies were conducted at the USDA-ARS High Plains Grasslands Research Station near Cheyenne, Wyoming (latitude $41^{\circ} 11^{\prime} \mathrm{N}$, longitude $104^{\circ} 54^{\prime} \mathrm{W}$ ) during 1978-1980. Elevation of the study area is $1,885 \mathrm{~m}$. Mean annual temperature is $9^{\circ} \mathrm{C}$, with January having the lowest mean monthly temperature $\left(-3^{\circ} \mathrm{C}\right)$ and July the highest $\left(20^{\circ} \mathrm{C}\right)$. Length of frost-free growing season is approximately 127 days per year, but considerable alfalfa growth may occur before the last frost of spring and after the first frost of fall. April-September precipitation averages $272 \mathrm{~mm}$; April-September precipitation was $276 \mathrm{~mm}$ in 1978, $339 \mathrm{~mm}$ in 1979 , and 200 $\mathrm{mm}$ in 1980 .

The experiments were established on irrigated Archerson sandy clay loam (Aridic Argiustoil). Analysis of the soil from the $0-15 \mathrm{~cm}$ depth showed $230 \mathrm{~kg} \mathrm{~N} \mathrm{ha}^{-1} ; 60 \mathrm{~kg} \mathrm{P} \mathrm{ha}^{-1} ; 140 \mathrm{~kg} \mathrm{~K}^{-1} ; 1,070 \mathrm{~kg}$ $\mathrm{Ca} \mathrm{ha}^{-1} ; 80 \mathrm{~kg} \mathrm{Mg} \mathrm{ha}^{-1}$; and a pH of 7.5

The 13 alfalfa cultivars tested were: 'Drylander', 'NC-Crl', 'Roamer', 'Travois', and 'Victoria' with creeping roots and the 
Table 1. Total dry matter harvested from 3 creeping-rooted and 3 tap-rooted alfalfa cultivars under 9 cutting treatments during 1979 ( 3 cuts).

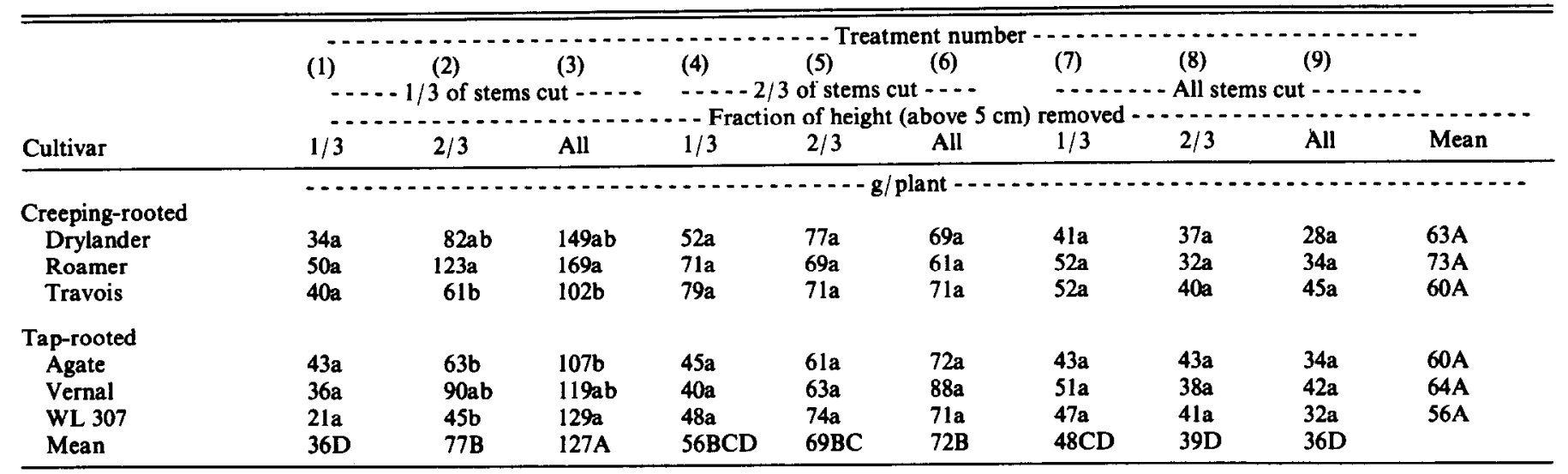

a,A Cultivar $X$ treatment means in the same column followed by the same lower-case letter and cutting treatment or cultivar means followed by the same upper-case letter are not significantly different ( 0.05 level, Tukey's Test).

ability to produce stems on these creeping or laterally spreading roots: 'Teton' with rhizomes; and 'Agate', 'Baker', 'Kanza', 'Ramsey', 'Riley', 'Vernal', and 'WL307' with taproot systems.

\section{The Clipping Experiment}

Six alfalfa cultivars (Drylander, Roamer, Travois, Agate, Vernal, and WL307) were seeded in the greenhouse on 10 June 1978 in sandy loam soil in clay pots $15 \mathrm{~cm}$ across and $15 \mathrm{~cm}$ deep. The seeds were scarified and inoculated with Rhizobium immediately before planting 1 seed per pot. Forty-five days after seeding, the plants were transplanted to the field. Each plot of $1 \mathrm{~m}^{2}$ consisted of 2 plants spaced $30 \mathrm{~cm}$ apart. A randomized complete block design with 4 replications was used. Each replication contained 54 plots (6 cultivars $\times 9$ treatments).

Clipping treatments were classified according to the fraction of the total number of stems that were clipped $(1 / 3,2 / 3$, or all) and the fraction of the height above $5 \mathrm{~cm}$ that was removed from the clipped stems $(1 / 3,2 / 3$, or all). Combinations of number of stems clipped and height of clipping produced 9 cutting treatments (Fig. 1).

Plants were clipped 4 June, 28 June, and 19 July in 1979; a severe hailstorm 31 July removed all top growth to ground level and precluded further clipping. In 1980, plants were clipped 28 May, 18 June, 9 and $30 \mathrm{July,}$, and 19 August, and the aftermath remaining after the last clipping was harvested to ground level on 3 Sep- tember. Clipped forage was dried $48 \mathrm{hr}$ at $70^{\circ} \mathrm{C}$, and the dry weight was recorded.

In both years, the alfalfa plants were first clipped at $10 \%$ bloom; Smith (1972) concluded grazing should be delayed until this stage to maintain productive stands. The optimum interval between defoliations is 35-45 days (Smith 1972, Irvine and McElgunn 1982), but the 21-day interval was chosen to increase defoliation stress and accelerate the response to clipping.

Crowns on each plant under treatments 1 through 6 were divided into 3 equal sectors. Under treatments 1,2 , and 3 , we clipped all stems from sector 1 at the first clipping, sector 2 at the second clipping, sector 3 at the third, sector 1 at the fourth, and sector 2 at the fifth. Under treatments 4, 5, and 6, we clipped all stems from sectors 1 and 2 at the first clipping, sectors 3 and 1 at the second clipping, sectors 2 and 3 at the third, etc. Under treatments, 7, 8, and 9 all stems were clipped at each clipping.

At the end of the experiment, on 10 September 1980, main crowns and tap roots to a depth of $30 \mathrm{~cm}$ were collected from all tap-rooted plants. Samples of creeping roots were randomly selected on creeping-rooted plants. The samples were dried and analysed for total nonstructural carbohydrate (TNC) by a modification of the method of Smith (1969). Amylglucodiase enzyme was used to hydrolyse starch and a colormetric procedure was used to determine reducing power.

Table 2. Total dry matter harvested from 3 creeping-rooted and 3 tap-rooted alfalfa cultivars under 9 cutting treatments during 1980 (5 cuts).

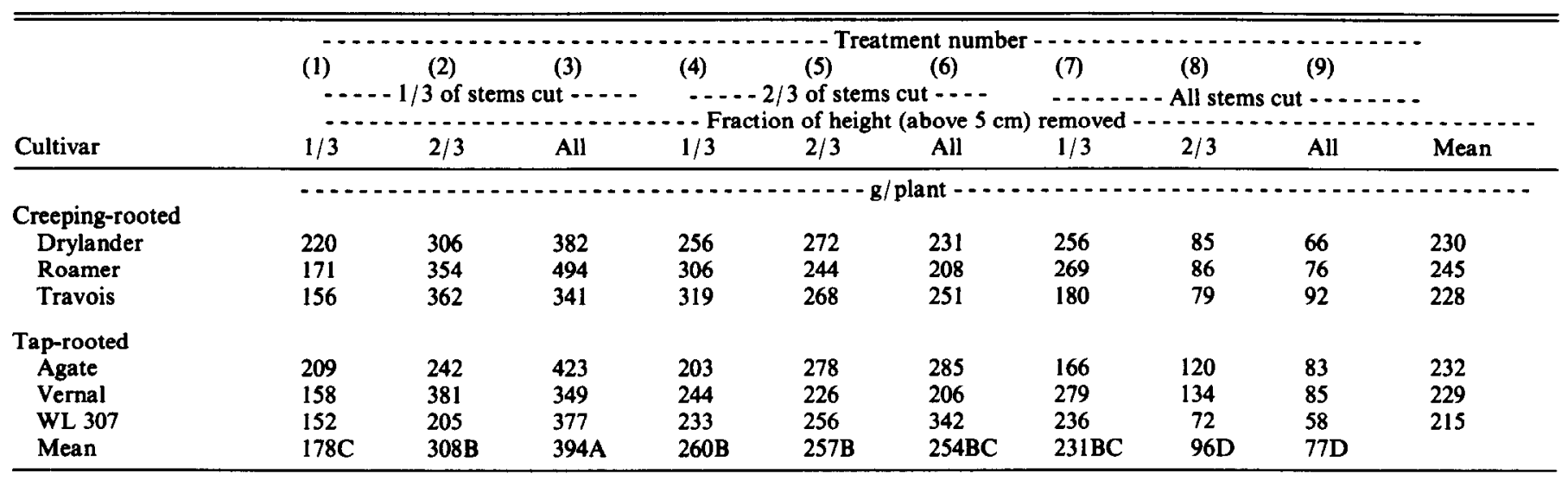

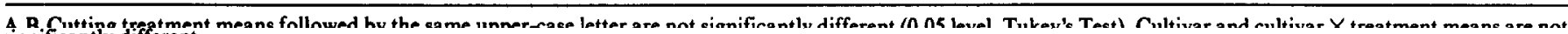

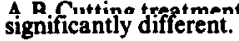


Table 3. Aftermath dry matter harvested from 3 creeping-rooted and 3 tap-rooted alfalfa cultivars following 5 cuts under 9 cutting treatments in 1980.

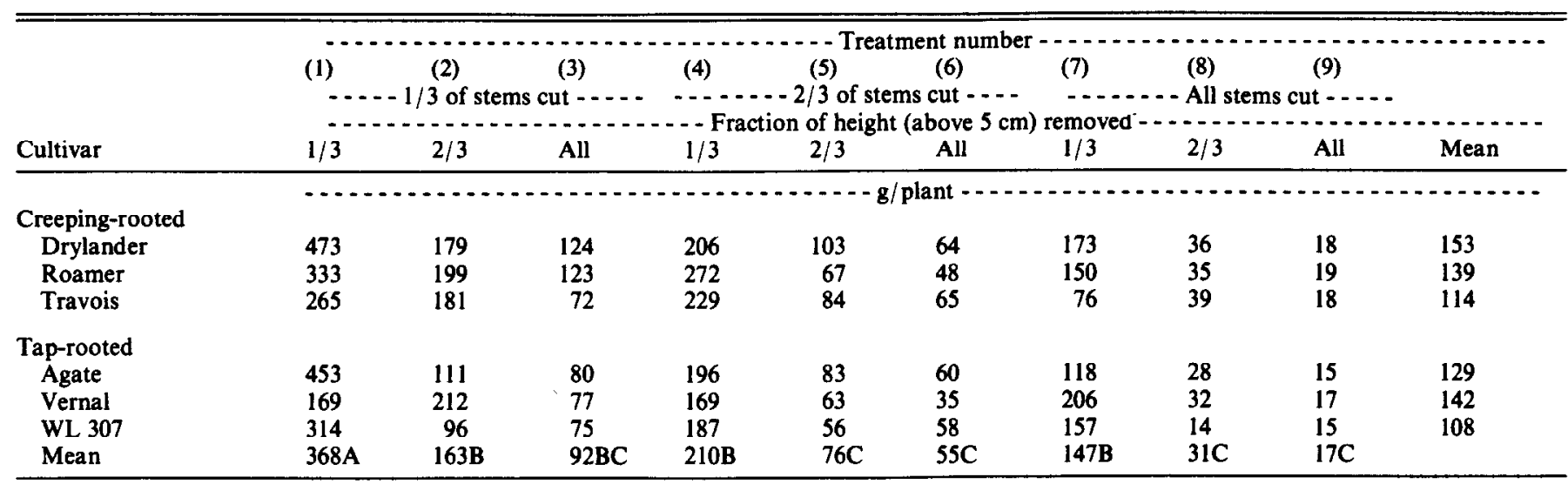

A,B Cutting treatment means followed by the same upper-case letter are not significantly different $(0.05$ level, Tukey's Test). Cultivar and cultivar $X$ treatment means are no significantly different.

\section{The Grazing Study}

All 13 alfalfa cultivars were used in this study. They were drillseeded in June 1978 in the field at $7 \mathrm{~kg} / \mathrm{ha}$ of pure live seed. Plots consisted of 5 rows $8 \mathrm{~m}$ long and $25 \mathrm{~cm}$ apart, in a randomized complete block design with 5 replications. Ranger alfalfa was seeded around the outside of the plot area to create a total area of alfalfa of 0.3 ha.

This area was grazed by 3 ewes on 25-29 June, and 2-7 and 9-14 July 1979; all remaining forage was clipped with a rotary mower 16 July and the area was grazed again 8-29 August. In 1980, the area was grazed by 5 ewes 27 May-14 June, 7-25 July, and 18-31 August. Stocking rates were equivalent to 11 animal-months/ha during the 1979 growing season and 26 animal-months/ha during the 1980 growing season. Ewes weighed 55 to $70 \mathrm{~kg}$ each. The percentage of row covered by plant crowns (basal cover) was estimated visually on 4 permanent $1-\mathrm{m}$ plots in each of the 3 center rows of each plot on 18 September 1978, 16 June and 22 September 1979, and 22 May and 20 September 1980.

\section{Data Analysis}

Analyses of variance and F-tests were performed on the forage dry matter yields of 1979,1980 , and both years together; on aftermath yields of 1980; on row cover; and on the TNC data. Tukey's test at the 0.05 level was used to separate means.

Row cover at the end of the 1980 grazing season was analyzed by covariance, using 1978 row cover as the covariate. Adjusted means were separated by Tukey's test at the 0.05 level.

\section{Results}

\section{Yield, Survival, and Root TNC Concentration under Clipping}

In 1979 treatment 3, in which one-third of the stems of each plant were cut at $5 \mathrm{~cm}$ above ground level while the other two-thirds were left uncut at each of the 3 clipping dates, produced the greatest forage dry matter (DM) yield (Table 1). Production was significantly reduced below treatment 3 when only two-thirds of the height was removed from one-third of the stems at each harvest (treatment 2). Cutting two-thirds of the stems at each harvest (treatments 4,5, and 6) produced the same amount of forage DM as treatment 2 , regardless of the fraction of height removed. Cutting all stems at each harvest (treatments 7,8 , and 9) produced no more forage DM, again regardless of height, than removing only one-third of the height of one-third of the stems at each harvest (treatment 1).

No significant differences were found among cultivar means. The only significant interaction found was among cultivars and treatments 2 and 3. Under both treatments, Roamer produced more forage than Agate or Travois, but under treatment 2 Roamer also produced more than WL 307.

In 1980, clipping effects on yield (Table 2) were similar to those in 1979. Treatment 3 again produced the highest forage yield, followed by treatments $2,4,5$, and 6 , which were not significantly different. But in 1980, removing one-third of the height of all stems on each plant (treatment 7) produced as much forage as any treatment except treatment 3 and more forage than removing two-thirds or all of the height from all the stems (treatments 8 and 9). Differences among cultivars and the cultivar $X$ treatment interaction were not significant.

All 6 cultivars under all treatments produced higher forage DM yields from the first 3 cuttings in 1980 than in 1979 when only 3 cuttings were taken. Mean yields from 3 cuts were 142 and 62 $\mathrm{g} /$ plant, respectively. Plants were a year older in 1980 and capable of much high yields. All plants established in 1978 survived through 1980, regardless of clipping treatment.

The most lenient cutting treatment, treatment 1 , was also the least productive treatment in 1979, and in 1980 produced more forage than only treatments 8 and 9 . Most of the production under treatment 1 remained in the uncut stubble, which contained more DM than that of any other treatment at the end of the season (Table 3). Less DM remained in stubble when two-thirds or all of the height of cut stems was removed than when only one third was removed, and when two-thirds or all of the stems were harvested rather than only one-third. No significant differences were found among stubble yields of the 6 cultivars.

Cultivars and the cultivar $\times$ treatment interaction had no effect on total nonstructural carbohydrate (TNC) concentrations in roots. Roots from treatment 1 had the highest TNC concentration of $42.5 \%$, followed by treatment 7 with $42.2 \% ; 2,41.8 \% ; 4,41.4 \%$; $3,40.8 \% ; 5,39.9 \% ; 6,38.9 \% ; 8,35.1 \%$; and $9,33.6 \%$. Concentrations of TNC under treatments 8 and 9 , the most severe cutting treatments, were significantly less than concentrations under other treatments.

Although roots of adjacent plants were so intermingled that an accurate root weight could not be obtainable, field observations indicated that root systems of all alfalfa cultivars tested became much smaller under more intensive clipping. Cutting alfalfa every 3 weeks not only reduced the rate of regrowth and decreased the yield, but also decreased the TNC concentration and reduced root growth which together reduced the total amount of TNC in the roots.

\section{Cover under Grazing}

Data collected in 1978 on stand establishment indicated significant differences among alfalfa cultivars. Crowns of WL 307 pro- 
duced the highest percentage of basal cover in the row, Riley the least, and Ramsey, Vernal, NC-Crl, Roamer, Agate, Victoria, Travois, Kanza, Drylander, Baker, and Teton intermediate, with no differences among them (Table 4).

Table 4. Proportion of row covered by crowns of 6 creeping-rooted and 7 tap-rooted alfalfa cultivars, 1978-1980.

\begin{tabular}{|c|c|c|c|c|c|c|}
\hline \multirow[b]{2}{*}{ Creeping-rooted } & 1978 & $\begin{array}{l}-\ldots 197 \\
\text { Pre- } \\
\text { grazing }\end{array}$ & $\begin{array}{l}79-.-1 \\
\text { Post- } \\
\text { grazing }\end{array}$ & $\begin{array}{l}\text { Pre- } \\
\text { grazing }\end{array}$ & $\begin{array}{l}--1980 \\
\text { - Post-g } \\
\text { Actual }\end{array}$ & $\begin{array}{l}\text { grazing - } \\
\text { Adjusted' }\end{array}$ \\
\hline & $\cdots$ & - - - & $--\% \mathrm{R}$ & Low cover & $r \ldots$ & $\ldots \ldots$ \\
\hline $\begin{array}{l}\text { Drylander } \\
\text { NC-Crl } \\
\text { Roamer } \\
\text { Teton } \\
\text { Travois } \\
\text { Victoria }\end{array}$ & $\begin{array}{l}62 b c \\
69 b \\
68 b \\
61 b c \\
63 b c \\
64 b c\end{array}$ & $\begin{array}{l}47 \\
47 \\
47 \\
56 \\
64 \\
53\end{array}$ & $\begin{array}{l}47 \\
51 \\
51 \\
56 \\
59 \\
47\end{array}$ & $\begin{array}{l}50 \\
59 \\
61 \\
66 \\
72 \\
54\end{array}$ & $\begin{array}{l}48 \\
50 \\
48 \\
53 \\
55 \\
43\end{array}$ & $\begin{array}{l}48 b \\
51 a b \\
50 a b \\
50 a b \\
48 b \\
48 b\end{array}$ \\
\hline $\begin{array}{l}\text { Tap-rooted } \\
\text { Agate } \\
\text { Baker } \\
\text { Kanza } \\
\text { Ramsey } \\
\text { Riley } \\
\text { Vernal } \\
\text { WL } 307\end{array}$ & $\begin{array}{l}63 \mathrm{bc} \\
61 \mathrm{bc} \\
63 \mathrm{bc} \\
70 \mathrm{~b} \\
57 \mathrm{c} \\
69 \mathrm{~b} \\
83 \mathrm{a}\end{array}$ & $\begin{array}{l}50 \\
36 \\
38 \\
51 \\
34 \\
52 \\
70\end{array}$ & $\begin{array}{l}48 \\
37 \\
44 \\
63 \\
37 \\
54 \\
69\end{array}$ & $\begin{array}{l}59 \\
44 \\
50 \\
62 \\
41 \\
64 \\
75\end{array}$ & $\begin{array}{l}53 \\
38 \\
46 \\
55 \\
36 \\
56 \\
67\end{array}$ & $\begin{array}{l}50 \mathrm{ab} \\
48 \mathrm{~b} \\
52 \mathrm{ab} \\
52 \mathrm{ab} \\
48 \mathrm{~b} \\
51 \mathrm{ab} \\
56 \mathrm{a}\end{array}$ \\
\hline
\end{tabular}

${ }^{1}$ Adjusted for initial differences in row cover.

a,b Means or adjusted means in the same column followed by the same letter are not significantly different ( 0.05 level, Tukey's Test). Unadjusted means in 1979 and 1980 were not analysed.

During the 1979 growing season, when the study area was grazed at a stocking rate of 11 animal-months/ha, sheep grazed primarily on leaves and branches; thick stems were left ungrazed and were removed by clipping. Sheep were observed to prefer Drylander and Travois first; Agate, Kanza and WL 307 last; and other cultivars in between. This result seems to be related to the thinner stems of Drylander and Travois, which are creeping-rooted cultivars, compared to the thick stems of Agate, Kanza and WL 307, which are tap-rooted cultivars.

During the 1980 growing season, when the study area was grazed at 26 animal-months/ha, sheep grazed the alfalfa plants more heavily than in 1979. Although they grazed on leaves and branches first, stems also were grazed. No appreciable amount of stubble was left at the end of each grazing period in 1980, although some stubble had been left after grazing and before clipping in 1979.

After 2 years of grazing, WL-307 (tap-rooted) had maintained more basal cover in the row (adjusted for 1978 levels) than Drylander, Travois, Victoria (all creeping-rooted), Baker, or Riley (both tap-rooted). All other cultivars were intermediate, with no differences among them.

\section{Discussion and Conclusions}

Folkins et al. (1961) reported that the yield of creeping-rooted Rhizoma was not significantly different from that of tap-rooted 'Grimm' over 5 years. Irvine and McElgunn (1982) reported that yields of tap-rooted 'Beaver' alfalfa were not significantly different from yields of creeping-rooted Roamer. On the other hand, Langille et al. (1965) found that Rhizoma yielded more than tap-rooted 'DuPuits' when the first cut was taken at a pre-bud stage followed by 2 cuts at the $50 \%$ flowering stage. Among tap-rooted cultivars, Kehr et al. (1963) found that adapted narrow-crowned alfalfa cultivars generally produced higher yields than did broad-crowned or creeping-rooted cultivars. Broad-crowned alfalfa cultivars were found to persist better than narrow-crowned cultivars under shorter intervals between harvests (Jung et al. 1969; Jones 1971). Yields of alfalfa cultivars may show a strong cultivar $X$ defoliation frequency interaction, particularly if cultivars vary in their adaptation to the area where they are tested.

As expected, forage production declined as intensity of defoliation increased (Graber et al. 1927, Smith 1972, Irvine and McElgunn 1982). But all cultivars, tap- or creeping-rooted, responded the same.

Again as expected, TNC concentrations in roots decreased as the intensity of defoliation increased (Graber et al. 1927, Smith 1972, Chatterton et al. 1974). TNC reserves in the roots of alfalfa plants are used to produce new top growth, and the decrease in TNC concentration continues until the plant has produced about 15 to $20 \mathrm{~cm}$ of new top growth (Smith 1972). Frequent or prolonged grazing does not permit enough top growth to persist for long enough to restore root carbohydrates, slowing recovery from defoliation and reducing forage production and plant survival. These effects can persist into the following year (Allen et al. 1986a and 1986b). But we found no differences among individual cultivars or between tap- and creeping-rooted cultivars.

Our study revealed no significant differences in forage production, survival, or root TNC concentrations between creeping- and tap-rooted alfalfas. Yet survival of the creeping-rooted cultivars 'Nomad' and 'Rhizoma,' after 7 years of grazing at Grouse Creek, Utah, was much better than that of 'Ladak', the only tap-rooted $M$. sativa cultivar to survive (Rumbaugh and Pedersen 1979). Twice as many plants of Rhizoma and 5 times as many plants of Nomad survived as plants of Ladak. Survival of the creeping-rooted Travois was as great as that of any tap-rooted cultivar, and better than that of 7 of the 21 tap-rooted cultivars, after 2 years of grazing (Counce et al. 1984). Berdahl et al. (1989) included several of the cultivars in our study in their study of 17-year-old alfalfa stands near Mandan, North Dakota. Mean survival of creeping-rooted Drylander, Roamer, and Travois was 6.0 plants $/ \mathrm{m}^{2}$, vs a mean of 2.0 plants $/ \mathrm{m}^{2}$ for Baker, Kanza, Ramsey, and Riley. Smith et al. (1989) reported that, after 3 years of grazing in Georgia, 6-9 plants $/ \mathrm{m}^{2}$ of tap-rooted hay-type alfalfas (Apollo and Florida 77) survived, vs $40-48$ plants $/ \mathrm{m}^{2}$ of creeping-rooted grazing type alfalfas (Travois, Spredor II, and GA-GC).

Greater survival of creeping-rooted alfalfas may be related less to an intrinsic capacity to recover from grazing than to the probability of escaping complete defoliation. In the clipping study, creeping-rooted cultivars produced stems as far as $2 \mathrm{~m}$ from the original plant. Under range conditions, plants may be widely spaced; Rumbaugh and Pedersen (1979) and Rosenstock and Stevens (1989) reported stands of 1.6 to 3.8 and 0.5 to 2.5 plants $/ \mathrm{m}^{2}$ respectively, comparable to our spacing of 2 plants $/ \mathrm{m}^{2}$. In such an open stand, the probability that some stems on each plant would remain ungrazed at each grazing event would be increased, although other stems might be completely removed. This is the defoliation pattern imposed in treatments 1 through 6 , which produced higher yields and TNC concentrations than treatments 7 through 9 in which all stems were defoliated simultaneously. Treatments 7,8 , and 9 resemble the way in which narrow-crowned, tap-rooted alfalfas are defoliated under grazing.

Pitelka and Ashmun (1985) concluded that formation of spreading clones via rhizomes or stolons favored higher rates of survival and more rapid recovery after defoliation in many species of perennial plants, including grasses, legumes, and other forbs. Cook (1985) stated "Sources of mortality that are intense but local in space would favor clonal reproduction. The effects of herbivores ... might operate in this way." Jeffries (1984) concluded that the probability of damage to a plant from grazing decreases as the number of stems or tillers increase. Gosse et al. (1988) suggested that competition among alfalfa stems for light may limit growth when stem densities are high; this is more likely to happen with 
tap-rooted than with creeping-rooted cultivars.

Thus the reported superiority of creeping-rooted cultivars, in view of the similar response of all cultivars to the treatments, may be caused by their ability to evade complete grazing and inter-tiller competition, rather than from any special ability to resist or recover rapidly from grazing. Rosenstock and Stevens (1989) also concluded that the survival of creeping-rooted alfalfas was related to their ability to evade complete defoliation, and cited the earlier work of Gdara (1985) in support. They and Berdahl et al. (1986) questioned whether rapid regrowth after defoliation was conducive to alfalfa survival in semiarid conditions. However, the proliferation of roots of creeping-rooted alfalfas under moderate defoliation (Carlson et al. 1964) may increase chances of survival.

This conclusion is not contradicted by the fact that all cultivars reacted similarly to grazing. In the grazing study, the alfalfa was planted at a heavy seeding rate; there was little opportunity for plants to spread (Kilcher and Heinrichs 1969, Daday et al. 1974) and creeping-rooted cultivars had little opportunity to evade complete grazing as they might have in a more open stand on rangeland. Hartnett (1989) found defoliation was equally damaging to switchgrass (Panicum virgatum L.) and big bluestem (Andropogon gerardii Vitman) in dense stands, but was much less damaging to the rhizomatous switchgrass than to bluestem in open stands.

\section{Literature Cited}

Allen, V.G., D.D. Wolf, J.P. Fontenot, J. Cardina, and D.R. Notter. 1986a. Yield and regrowth characteristics of alfalfa grazed with sheep. I. Spring grazing. Agron. J. 78:974-979.

Allen, V.G., L.A. Hamilton, D.D. Wolf, J.P. Fontenot, T.H. Terrill, and D.R. Notter. 1986b. Yield and regrowth characteristics of alfalfa grazed with sheep. II. Summer grazing. Agron. J. 78:979-985.

Ashford, R., and D.H. Heinrichs. 1967. Grazing of alfalfa varieties and observations of bloat. J. Range Manage. 20:152-153.

Berdahl, J.D., A.C. Wilson, and A.B. Frank. 1989. Survival and agronomic performance of 25 alfalfa cultivars and strains interseeded into rangeland. J. Range Manage. 42:312-316.

Carlson, G.E., V.G. Sprague, and J.B. Washko. 1964. Effects of temperature, daylength, and defoliation on the creeping-rooted habit of alfalfa. Crop Sci. 14:284-286.

Chatterton, N.J., G.E. Carlson, R.H. Hart, and W.E. Hungerford. 1974. Tillering, nonstructural carbohydrates, and survival relationships in alfalfa. Crop Sci. 14:783-787.

Clark, K.W.1960. Persistence of 'Rambler' alfalfa under grazing. Rep. 17th Alfalfa Imp. Conf., p. 99-106.

Cook, R.E. 1985. Growth and development in clonal plant populations. p. 259-296. In: Jackson, J.B.C., L.W. Buss, and R.E. Cook (eds.) Population biology and evolution of clonal organisms. Yale University Press, New Haven.

Counce, P.A., J.H. Bouton, and R.H. Brown. 1984. Screening and characterizing alfalfa for persistence under mowing and continuous grazing. Crop Sci. 24:282-285

Daday, H. 1968. Heritability and genotypic and environmental correlations of creeping root and persistency in Medicago sativa L. Aust. J. Agr. Res. 19:27-34.
Daday, H., A. Grassia, and J. Peak. 1974. Effect of plant density on the expression of the creeping-rooted character and forage yield of the lucerne (Medicago sativa) cultivar Cancreep. Aust. J. Exp. Agr. Anim Husb. 14:735-741.

Folkins, L.P., J.E.R. Greenshields, and F.S. Nowosad. 1961. Effect of date and frequency of defoliation on yield and quality of alfalfa. Can. J. Plant Sci. 41:188-194.

Gdara, A.0. 1985. The effect of grazing and various intensities of clipping on the regrowth and survival of several alfalfa cultivars. Ph.D. Diss., Colorado State University, Ft. Collins. Diss. Abstr. Int. 46:1777-1778B.

Gosse, G., C. Lemaire, M. Charlier, and F. Balfourier. 1988. Structure of a lucerne population (Medicago sativa $\mathrm{L}$.) and dynamics of stem competition for light during regrowth. J. Appl. Ecol. 25:609-617.

Graber, L.F., N.T. Nelson, W.A. Luekel, and W.B. Albert. 1927. Organic food reserves in relation to the growth of alfalfa and other perennial herbaceous plants. Wisconsin Agr. Exp. Sta. Res. Bull. 80.

Hartnett, D.C. 1989. Density- and growth stage-dependent responses to defoliation in two rhizomatous grasses. Oecologia 80:414-420.

Heinrichs, D.H., and J.L. Bolton. 1985. 'Rambler' alfalfa. Canada Dep. Agr. Pub. 1030.

Irvine, R.B., and J.D. McElgunn. 1982. Effect of eight three-cut harvesting schedules on production of alfalfa forage under irrigation in southwestern Saskatchewan. Can. J. Plant Sci. 62:107-110.

Jeffries, R.L. 1984. The phenotype: its development, physiological constraints and environmental signals. p. 347-358. In: R. Dirzo and J. Sarukhan (eds.) Perspectives on plant population ecology. Sinaver Assoc., Inc., Sunderland, Mass.

Jones, E.R. 1971. Carbohyd rate reserves in alfalfa (Medicago sativa L.) as influenced by several management factors. PhD Diss., Univ. of Saskatchewan, Saskatoon. Diss. Abstr. Int. 30:4878B.

Jung, G.A., D. Smith, and J.A. Balasko. 1969. Studies on yield, management, persistence and nutritive value of alfalfa in West Virgina. West Virginia Agr. Exp. Sta. Bull. 581T.

Kehr, W.R., E.C. Conard, M.A. Alexander, and F.C. Owen. 1963. Performance of alfalfa under five management systems. Nebraska Agr. Exp. Sta. Res. Bull. 211

Kilcher, M.R., and D.H. Heinrichs. 1966. Persistence of alfalfas in mixture with grasses in a semiarid region. Can. J. Plant Sci. 46:163-167.

Kilcher, M.R., and D.H. Heinrichs. 1969. Influence of row spacing on yield and creeping root development of 'Rambler' alfalfa in a semiarid region. Can. J. Plant Sci. 49:307-311.

Langille, J.E., L.B. MacLeod, and F.S. Warren. 1965. Influence of harvesting management on yield, carbohydrate reserves, etiolated regrowth and potassium utilization of alfalfa. Can. J. Plant Sci. 45:383-388.

Leach, G.J. 1969. Shoot numbers, shoot size, and yield of regrowth in three lucerne cultivars. Aust. J. Agr. Res. 20:425-434.

Pitelka, L.F., and J.W. Ashmun. 1985. Physiology and integration of ramets in clonal plants. p. 399-435 In: Jackson, J.B.C. L. W. Buss, and R.E. Cook (eds.) Population biology and evolution of clonal organisms. Yale University Press, New Haven.

Rosenstock, S.S., and R. Stevens. 1989. Herbivore effects on seeded alfalfa at four pinyon-juniper sites in central Utah. J. Range Manage. 42:483-490

Rumbaugh, M.D., and M.W. Pedersen. 1979. Survival of alfalfa in five semiarid range seedings. J. Range Manage. 32:48-51.

Smith, D. 1969. Removing and analysing total nonstructural carbohydrates from plant tissue. Wisconsin Agr. Exp. Sta. Res. Rep. 41.

Smith, D. 1972. Cutting schedules and maintaining pure stands in alfalfa In: C.H. Hanson (ed.) Alfalfa science and technology. Agron. 15:481-496

Smith, S.R. Jr., J.H. Bouton, and C.S. Hoveland. 1989. Alfalfa persistence and regrowth potential under continuous grazing. Agron. J. 81:960-965. 